\title{
Efficiency Enhancement in Polycrystalline CdS/CdTe Solar Cell via Diffraction Grating and Engineering Absorber and Back Surface Field Layers
}

\author{
M. MAHOODI \\ Department of Electrical Engineering, Ferdowsi University of Mashhad, Mashhad 9177948974, Iran \\ malihe.mahoodi@mail.um.ac.ir
}

Received 27/08/2018 - Accepted 16/11/2018

DOI: $10.15628 /$ holos.2018.7668

\begin{abstract}
In this paper, the effect of diffraction grating and engineering absorber and back surface field (BSF) layers on performance of a single-junction polycrystalline cadmium sulfide/cadmium telluride ( $\mathrm{CdS} / \mathrm{CdTe}$ ) solar cell have investigated. At first, the electrical characteristics of reference $\mathrm{CdS} / \mathrm{CdTe}$ solar cell is simulated and validated with experimental data of fabricated CdS/CdTe solar cell. In order to improve the maximum efficiency, a new structure with diffraction grating and engineering absorber and back surface field layers is presented. Furthermore, the effect of carrier
\end{abstract}

lifetime variation in the absorber layer on the conversion efficiency of solar cell was investigated. It is found that diffraction grating and engineering absorber and back surface field layers can increase the conversion efficiency of the solar cell by about $1.02 \%$ and $6 \%$ compared with reference cell, respectively. Under global AM 1.5 conditions, the open circuit voltage, short circuit current density, fill factor and conversion efficiency of optimized solar cell structure are $1114 \mathrm{mV}, 25.35$ $\mathrm{mA} / \mathrm{cm}^{2}, \quad 0.8856$ and $25.022 \%$, respectively.

KEYWORDS: Cadmium sulfide/cadmium telluride, polycrystalline CdS/CdTe solar cell, conversion efficiency, diffraction grating, engineering absorber and back surface field layers, carrier lifetime.

\section{Melhoria da eficiência em célula solar $\mathrm{CdS} / \mathrm{CdTe}$ policristalino por meio de grades de difração e engenharia camadas absorvedor e campo de superfície traseira}

\section{RESUMO}

Neste trabalho, investigou-se o efeito das camadas de difração de grade e absorção de engenharia e de campo de superfície posterior (BSF) sobre o desempenho de uma célula solar policristalina de sulfeto de cádmio/cádmio ( $\mathrm{CdS} / \mathrm{CdTe})$ Inicialmente, as características elétricas da célula solar $\mathrm{CdS} / \mathrm{CdTe}$ de referência são simuladas e validadas com dados experimentais da célula solar CdS/CdTe fabricada. A fim de melhorar a eficiência máxima, é apresentada uma nova estrutura com camadas de difração de grade e absorvedor de engenharia e de campo de superfície posterior. Além disso, o efeito da variação da vida útil da transportadora na camada absorvente na eficiência de conversão da célula solar foi investigado. Descobriu-se que as camadas de campo de difração e de absorção de engenharia e de superfície posterior podem aumentar a eficiência de conversão da célula solar em cerca de 1,02\% e 6\% em comparação com a célula de referência, respectivamente. Sob condições globais AM 1.5, a tensão de circuito aberto, densidade de corrente de curto-circuito, fator de enchimento e eficiência de conversão da estrutura da célula solar otimizada são $1114 \mathrm{mV}, 25,35 \mathrm{~mA} / \mathrm{cm}^{2}, 0,8856$ e $25,022 \%$, respectivamente.

Palavras-Chave: Sulfeto de cádmio / telureto de cádmio, Célula solar CdS / CdTe policristalino, Eficiência de conversão, Grade de difração, Engenharia camadas absorvedor e campo de superfície traseira, Duração da portadora. 


\section{INTRODUCTION}

Solar energy can be converted using photovoltaics that can be made using crystalline materials, multiple-junctions, or polycrystalline thin films. Although, polycrystalline thin films such as CIGS or cadmium telluride (CdTe) have several potential advantages. Polycrystalline thin films reduce cost and materials needs because the materials usage is much lower. On the other hands, less material and lower purity requirements cause lower embodied energy. Therefore, the energy payback time can be well under a year (Marjani, et al., 2016; Sabaghi, et al., 2015). The CdTe cells have underperformed crystalline Silicon cells but the $\mathrm{CdTe}$ is also easily manufacturable by various methods including the closed space sublimation, vapor transport deposition, or molecular beam epitaxy (Khosroabadi, et al., 2014). In recent years, the efficiency of these cells have increased but further gains in efficiency will continue to be beneficial. Since the same area or number of panels can provide more energy, improved efficiency helps to reduce the cost of the cells and panels and balance of system costs. Therefore, solar photovoltaics better able to supply the world's energy needs.

The thickness of CdS is one of important factor in the conversion efficiency of cadmium sulfide/cadmium telluride (CdS/CdTe) solar cell. Reducing the CdS layer thickness causes high short circuit current densities (Krishnakumar, et al., 2011). Generally, CdTe films are usually deposited by the close-spaced sublimation (CSS), electrodeposition, spraying, or screen printing techniques and by Chemical bath deposition (CBD), vacuum evaporation, or CSS methods. On the other hands, because of limited availability and the rising price of telluride with regards to very high volume photovoltaic module manufacture in the future, reducing the CdTe absorber layer thickness is important prospect. In order to form an ohmic contact, Amin proposed a ZnTe buffer layer as a back surface reflector (Amin, et al., 2007).

Previous researchers reported $16.4 \%$ and $21.5 \%$ for maximum cell efficiency of $\mathrm{CdS} / \mathrm{CdTe}$ solar cells (Green, et al., 2016; Kosyachenko, et al., 2009; Britt and Ferekides, 1993; Pena, et al., 2011; Colegrove, et al., 2012). The National Renewable Energy Laboratory (NREL) reports record efficiencies of $21.5 \%$ and $22.1 \%$ for cell efficiency; and $16.1 \%$ and $18.6 \%$ for module efficiency at the lab condition for CdS/CdTe solar cells (First Solar Inc., 2014) that have increased by only 3.2\% during the last 20 years (Razykov, et al., 2011; Rios-Flores, et al., 2012; Aramoto, et al., 1997; Wu, et al., 2001; Sabaghi, et al., 2015; Mahoodi and Marjani, 2017a; Mahoodi and Marjani, 2017b; Mahoodi and Marjani, 2017c; Mahoodi et al., 2018). Therefore, increasing the efficiency is major challenge of $\mathrm{CdS} / \mathrm{CdTe}$ thin film solar cells.

In this paper, in order to further improve the performance of single-junction polycrystalline $\mathrm{CdS} / \mathrm{CdTe}$ solar cell, we used diffraction grating and engineering absorber and back surface field (BSF) layers. All of the simulation results is compared with already-fabricated and simulated $\mathrm{CdTe} / \mathrm{CdS}$ cell structure as a reference cell. In addition, optimization of the carrier lifetime is made for achieving the highest efficiency. The rest of this paper is described as follows: The structure, model and its validation are described in section 2. Section 3 presents the results and discussion. Finally, we conclude in section 4.

\section{DEVICE STRUCTURE, MODEL and ITS VALIDATION}

It is essential to take into account the interaction of optical and electrical that occur during the solar cells operation when modeling thin film solar cells. The fundamental equations are electrostatic potential and carrier densities, which link together. The primary equations are Poisson's Equation, the continuity equations and transport equations that derived from 
Maxwell's laws. These equations are solved self-consistently with Silvaco ATLAS oftware [Online: http://www.silvaco.com/products/device_simulation/atlas.html]. In order to model the dopingdependent low-field mobility, recombination model and carrier lifetimes, the ConcentrationDependent Low Field Mobility model, Shockley-Read-Hall recombination model and SRH Concentration-Dependent Lifetime were used.

An experimentally-fabricated $\mathrm{CdS} / \mathrm{CdTe}$ solar cell has been used as a reference cell and our simulation results are very close to the previous experimental results (Amin, et al., 2007). Therefore, the results can be basically valid for an actual cell with the proposed configuration. Figure. 1 shows the reference cell structure where glass is used as the substrate. Structure was consisted of $200 \mathrm{~nm}$ indium-tin-oxide (ITO), 50nm CdS, 3.5 $\mu \mathrm{m}$ CdTe. All parameters used for simulation CdS/CdTe solar cell have been listed in Table 1. Under AM 1.5 conditions, simulated structure shows an open circuit voltage of $988 \mathrm{mV}$, a short circuit current density of 22.14 $\mathrm{mA} / \mathrm{cm}^{2}$, a fill factor of 0.823 , and a conversion efficiency of $18 \%$. Table 2 compares the experimental results of open circuit voltage $\left(\mathrm{V}_{\mathrm{OC}}\right)$, short circuit current density $\left(\mathrm{J}_{\mathrm{SC}}\right)$, fill factor, and cell efficiency with the simulated ones. As can be seen, the simulated results are quite close to the actual experimental data (Amin, et al., 2007).

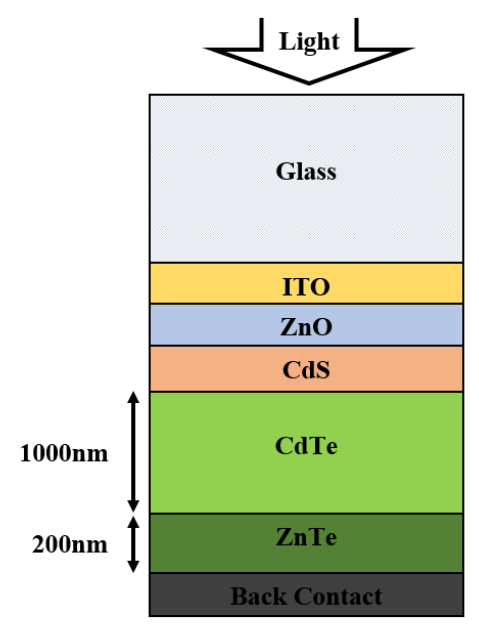

Figure 1: The schematic structure of the reference cell (Amin, et al., 2007).

\section{RESULTS AND DISCUSSION}

At first, we investigated the effect of step doping grading of absorption layer by creating a built-in electrical field in the CdTe layer. In this way, the absorption layer is divided into two layers with different doping concentration of $10^{14}-10^{17} \mathrm{~cm}^{-3}$ and $10^{18} \mathrm{~cm}^{-3}$ for top and bottom layers, respectively. The thickness of layers were considered $150 \mathrm{~nm}$. Figure. 2 shows the proposed structure with step doping grading of absorption layer for optimization of the cell performance.

Figure. 3 shows the performance of the proposed structure with step doping grading of absorption layer as a function of doping concentration of top CdTe layer. A built-in electric field in the CdTe layer has been created by the step doping grading of absorption layer that assists carrier migration. Therefore, it reduces the series resistance and charge storage time. As can be seen, the performance is maximized with doping concentration of $7 \times 10^{17} \mathrm{~cm}^{-3}$ and $2 \times 10^{18} \mathrm{~cm}^{-3}$ for top and bottom CdTe layers. Under global AM 1.5 conditions, the designed cell had an open 
Table.1: Physical parameters for simulation CdS/CdTe solar cell.

\begin{tabular}{|c|c|c|}
\hline & $\mathrm{CdS}$ & $\mathrm{CdTe}$ \\
\hline $\mathrm{m}_{\mathrm{n}}^{*} / \mathrm{m}_{\mathrm{o}}$ & 0.171 & 0.25 \\
\hline $\mathrm{m}_{\mathrm{p}}^{*} / \mathrm{m}_{\mathrm{o}}$ & 0.7 & 0.7 \\
\hline Dielectric Constant $\varepsilon / \varepsilon_{0}$ & 10 & 9.4 \\
\hline Electron Affinity [eV] & 4.3 & 4.28 \\
\hline Electron Mobility $\mu_{\mathrm{e}}\left[\mathrm{cm}^{2} / \mathrm{Vs}\right]$ & 350 & 500 \\
\hline Hole Mobility $\mu_{\mathrm{h}}\left[\mathrm{cm}^{2} / \mathrm{Vs}\right]$ & 50 & 60 \\
\hline Electron/Hole Density n, $\mathrm{p}\left[\mathrm{cm}^{-3}\right]$ & $\mathrm{n}: 10^{16}$ & $\mathrm{p}: 10^{14}$ \\
\hline Band Gap Energy $E_{\mathrm{g}}[\mathrm{eV}]$ & 2.42 & 1.45 \\
\hline Effective Density of States $\mathrm{N}_{\mathrm{C}}\left[\mathrm{cm}^{-3}\right]$ & $2.4 \times 10^{18}$ & $8 \times 10^{17}$ \\
\hline Effective Density of States $N_{V}\left[\mathrm{~cm}^{-3}\right]$ & $1.8 \times 10^{19}$ & $1.8 \times 10^{18}$ \\
\hline Capture Cross Section $\left[\mathrm{cm}^{2}\right]$ & $\mathrm{e}: 10^{-17} \mathrm{~h}: 10^{-12}$ & $\mathrm{e}: 10^{-11} \mathrm{~h}: 10^{-14}$ \\
\hline Acceptor/Donor Defect Density $\mathrm{N}_{\mathrm{DG}}, \mathrm{N}_{\mathrm{AG}}\left[\mathrm{cm}^{-3}\right]$ & A: $10^{17}$ & D: $2 \times 10^{14}$ \\
\hline Defect Peak Energy $E_{A}, E_{D}[e V]$ & midgap & midgap \\
\hline Distribution Width $\mathrm{W}_{\mathrm{G}}[\mathrm{eV}]$ & 0.1 & 0.1 \\
\hline
\end{tabular}

Table.2: Comparison between the characteristics of the simulated cell and the reference cell.

\begin{tabular}{ccc}
\hline \hline Parameters & Reference cell (Amin, et al., 2007) & Simulated cell \\
\hline \hline $\mathrm{V}_{\mathrm{OC}}(\mathrm{mV})$ & 985 & 988 \\
\hline $\mathrm{J}_{\mathrm{SC}}\left(\mathrm{mA} / \mathrm{cm}^{2}\right)$ & 22.2 & 22.14 \\
\hline Fill factor & 0.830 & 0.823 \\
\hline Efficiency $(\%)$ & 18.12 & 18 \\
\hline
\end{tabular}

circuit voltage of $1112 \mathrm{mV}$, a short circuit current density of $23.23 \mathrm{~mA} / \mathrm{cm}^{2}$, and a fill factor of 0.88 , corresponding to a conversion efficiency of $22.907 \%$.

In this stage, in order to increase the efficiency of the polycrystalline CdS/CdTe/ZnTe cell, a built-in electrical field was formed in the ZnTe layer by step doping grading. In this way, the ZnTe layer was divided into two layers with different doping levels. Top and bottom layers were $150 \mathrm{~nm}$ thick with $10^{14}-10^{18} \mathrm{~cm}^{-3}$ doping concentration and $150 \mathrm{~nm}$ thick with $10^{18} \mathrm{~cm}^{-3}$ doping concentration. Figure. 4 shows this structure with step doping grading in the ZnTe layer that doping of top ZnTe layer was varied from $10^{14} \mathrm{~cm}^{-3}$ to $10^{18} \mathrm{~cm}^{-3}$.

The variation of the doping concentration of the top ZnTe layer for different doping of bottom ZnTe layer are shown in figure. 5 . Ass seen, the efficiency decreases when the doping 


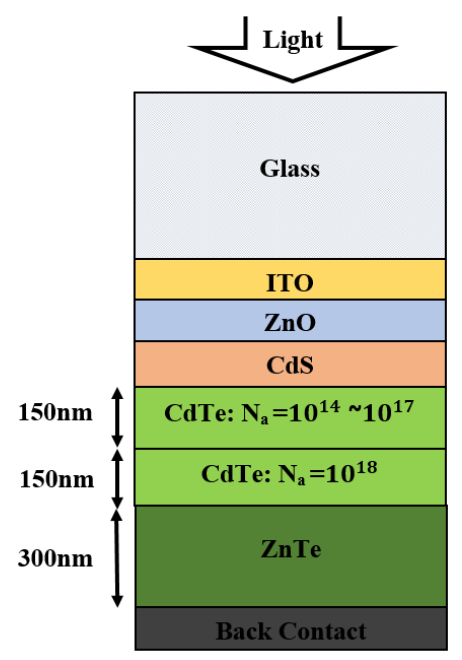

Figure 2: The configuration of the polycrystalline $\mathrm{CdS} / \mathrm{CdTe}$ cell with step doping in the CdTe layer.

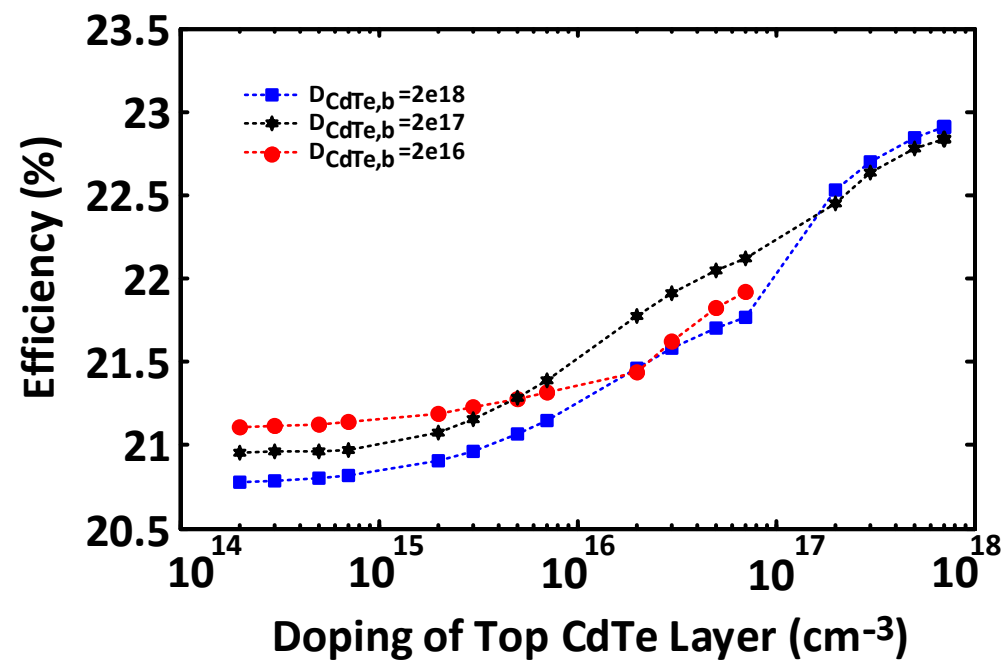

Figure 3: The efficiency of the designed cell as a function of doping concentration of top CdTe layer.

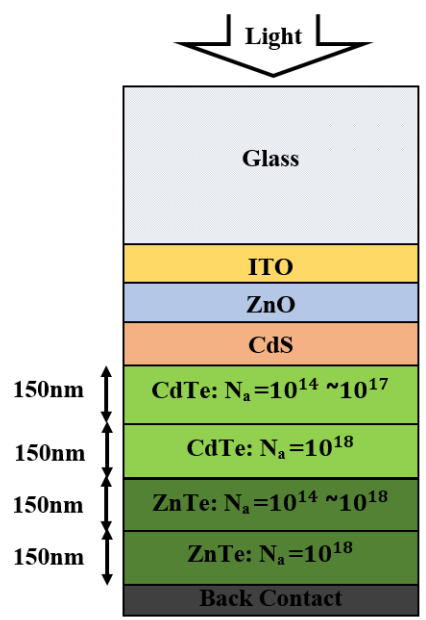

Figure 4: The schematic structure with stepped doping grading of the $\mathrm{ZnTe}$ layer. 
concentration of top ZnTe layer increases. Due to both high built-in electrical field and high absorption level, the efficiency was highest for doping concentration of $10^{15} \mathrm{~cm}^{-3}$. However builtin electrical field and absorption are constant before doping concentration of $10^{15} \mathrm{~cm}^{-3}$. On other hands, the built-in electrical field is low and the absorption is high after doping concentration of $10^{15} \mathrm{~cm}^{-3}$.

In order to achieve best device performance, various designs using different length of $\mathrm{CdTe}$ and ZnTe layers of diffraction grating were investigated. The charge storage time was decreased considerably to improve performance of the polycrystalline CdS/CdTe/ZnTe cell structure by increasing the length of CdTe of diffraction grating. Therefore, length of CdTe and $\mathrm{ZnTe}$ layers of diffraction grating were both optimized, however the doping concentration of the layers remained unchanged. The structure of polycrystalline $\mathrm{CdS} / \mathrm{CdTe} / \mathrm{ZnTe}$ cell with diffraction grating including $\mathrm{CdTe}$ and $\mathrm{ZnTe}$ layers was shown in figure. 6. Figure. 7 shows the cell efficiency of the new structure as a function of different length of CdTe and $\mathrm{ZnTe}$ layers of diffraction grating. As can be seen from figure. 7, the efficiency is maximum for 200 and $50 \mathrm{~nm}$ of CdTe and ZnTe layers in diffraction grating, respectively. As compared to the reference cell, polycrystalline $\mathrm{CdS} / \mathrm{CdTe} / \mathrm{ZnTe}$ cell with diffraction grating exhibited higher efficiencies. The best diffraction grating structure shows performance of $24.47 \%$ and a fill factor of 0.885 , which is of particular importance in the solar cell design.

Figures. 8 and 9 show polycrystalline CdS/CdTe/ZnTe cell with tandem diffraction grating including CdTe and ZnTe layers and the current and power curves as a function of voltage, respectively. The results show the maximum conversion efficiency of $25.022 \%$ with the open circuit voltage, short circuit current density and fill factor of $1114 \mathrm{mV}, 25.35 \mathrm{~mA} / \mathrm{cm}^{2}$ and 0.8856 , respectively under global AM 1.5 conditions.

Since the carrier lifetime of CdTe has a strong influence on the solar cell fill-factor and the voltage calculation, we investigate the impact of carrier lifetime in the CdTe layer on the $\mathrm{J}_{\mathrm{SC}}, \mathrm{V}_{\mathrm{OC}}$, FF and Efficiency of the proposed cell to improve the further efficiency. The variations of carrier lifetime can be modeled by variation of defect density. Increased defect density and purity of the CdTe alters the electron lifetime as well as the hole lifetime. Physically, a reduction in the defect density could be the key to improvement in increased lifetime through a smaller number of recombination centers. All carriers generated in the depletion region will be collected at higher lifetimes. Therefore, the $V_{O C}$ and conversion efficiency improve with increasing the carrier lifetime. The $V_{O C}$ is defined as:

$$
V_{O C}=\frac{n k T}{q} \ln \left(\frac{J_{S C}}{J_{o}}+1\right)
$$

where $\mathrm{n}$ is the ideally factor. $\mathrm{k}, \mathrm{T}, \mathrm{q}$ and $\mathrm{J}_{\mathrm{SC}}$ are Boltzmann's constant, absolute temperature, electrical charge and short current density. $J_{0}$ is dark current density that is directly linked to the defect density and purity of the material. As can be seen, the $V_{O C}$ can be increased with decreasing dark current density (Jensen, et al., 2016).

Figure. 10 shows the $\mathrm{J}_{\mathrm{SC}}, \mathrm{V}_{\mathrm{OC}}, \mathrm{FF}$ and Efficiency of cell as a function of carrier lifetime. As seen, longer carrier lifetimes resulted in a higher $V_{\text {oc. }}$. Therefore, the conversion efficiency increases with increasing carrier lifetime.

data (Amin, et al., 2007). 


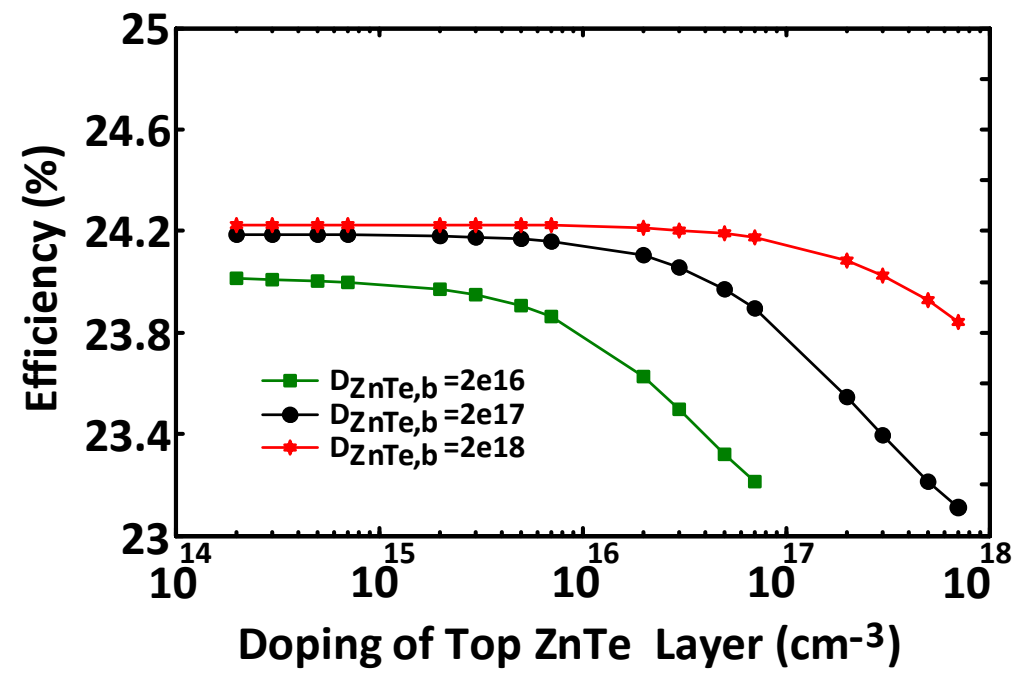

Figure 5: The efficiency as a function of the top ZnTe layer doping concentration.

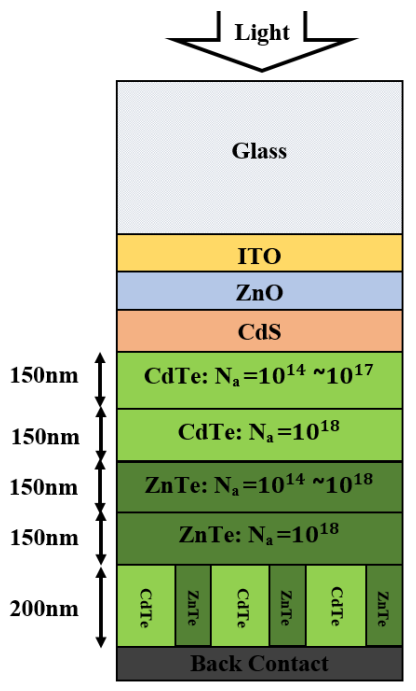

Figure 6: The schematic structure with diffraction grating including CdTe and ZnTe layers.

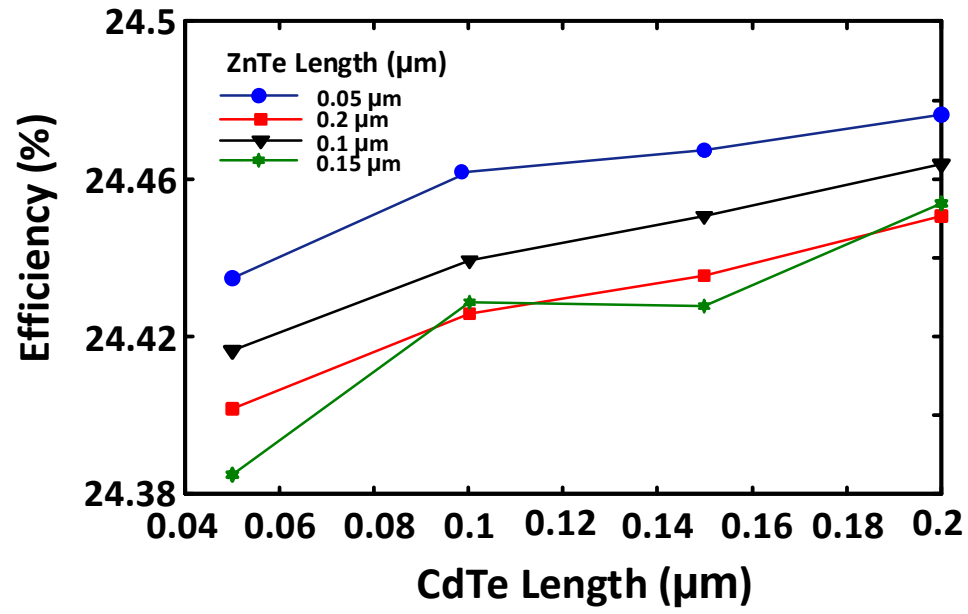


Figure 7: The cell efficiency as a function of different length of CdTe and ZnTe layers of diffraction grating.

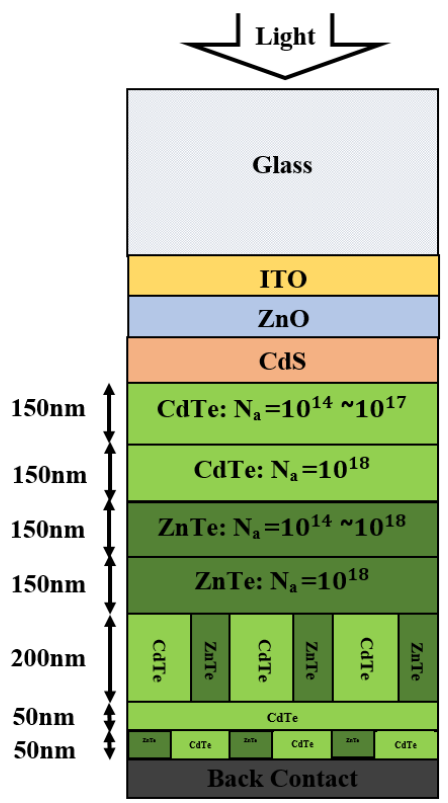

Figure 8: polycrystalline $\mathrm{CdS} / \mathrm{CdTe} / \mathrm{ZnTe}$ cell with tandem diffraction grating including $\mathrm{CdTe}$ and $\mathrm{ZnTe}$ layers.

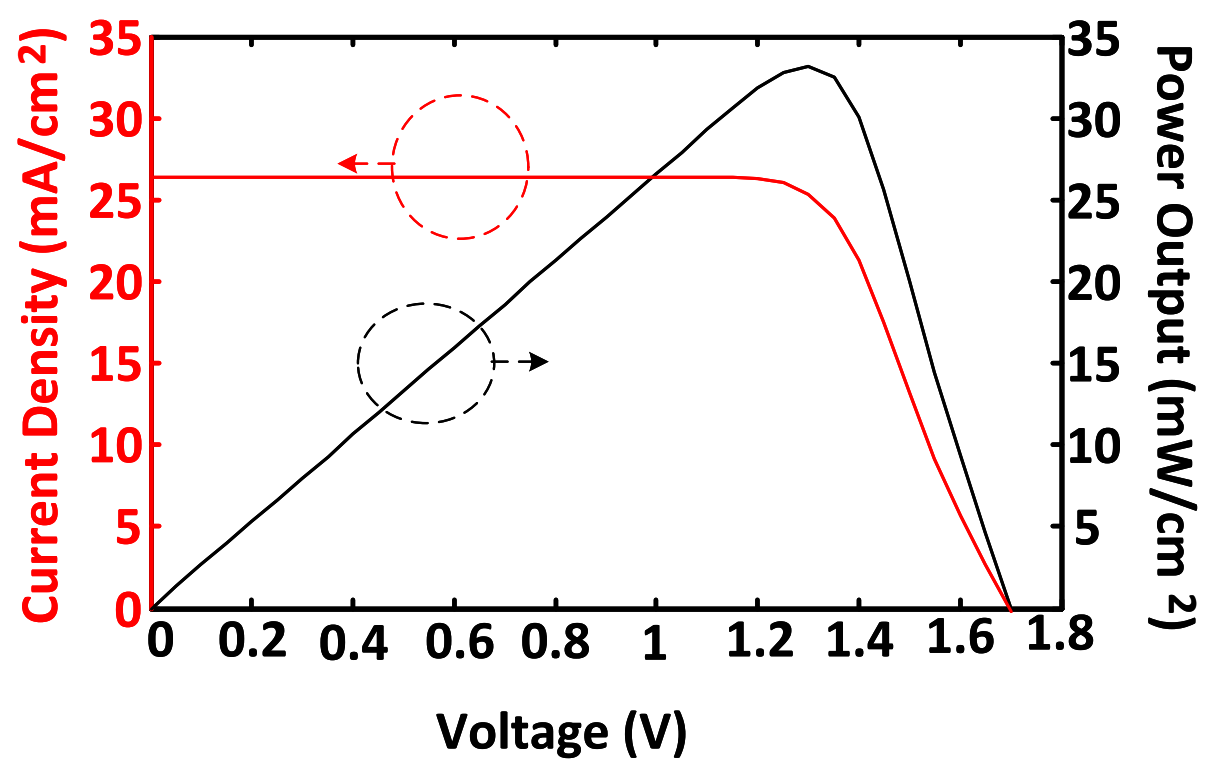

Figure 9: The power characteristics and current-voltage of the designed cell under global AM 1.5 conditions.

\section{CONCLUSION}

In this paper, a new structure is proposed which is achieved by diffraction grating and engineering absorber and back surface field layers in order to achieve the maximum efficiency. Also, the effect of carrier lifetime variation in the absorber layer on the conversion efficiency of solar cell was investigated. The results show the maximum conversion efficiency of $25.022 \%$ with 
the open circuit voltage, short circuit current density and fill factor of $1114 \mathrm{mV}, 25.35 \mathrm{~mA} / \mathrm{cm}^{2}$ and 0.8856 , respectively under global AM 1.5 conditions.

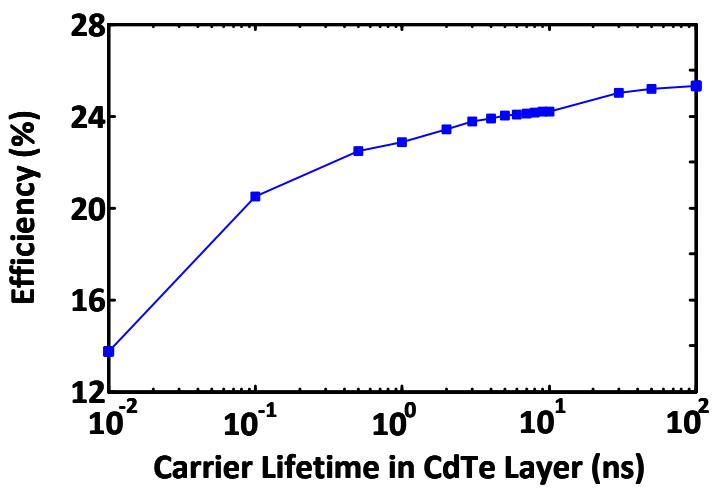

(a)

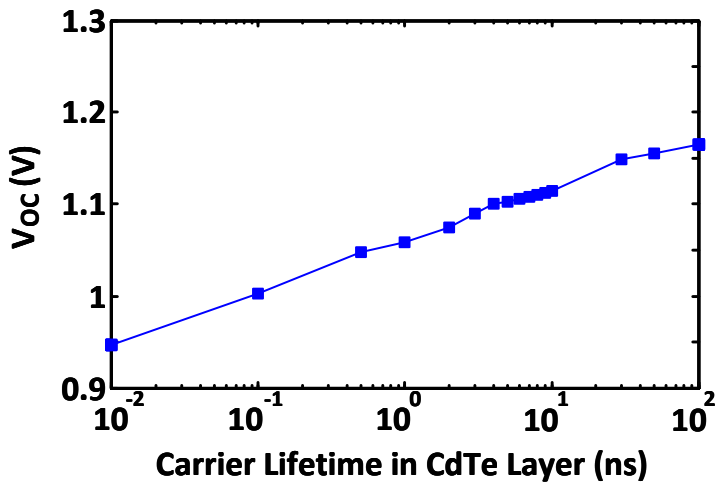

(c)

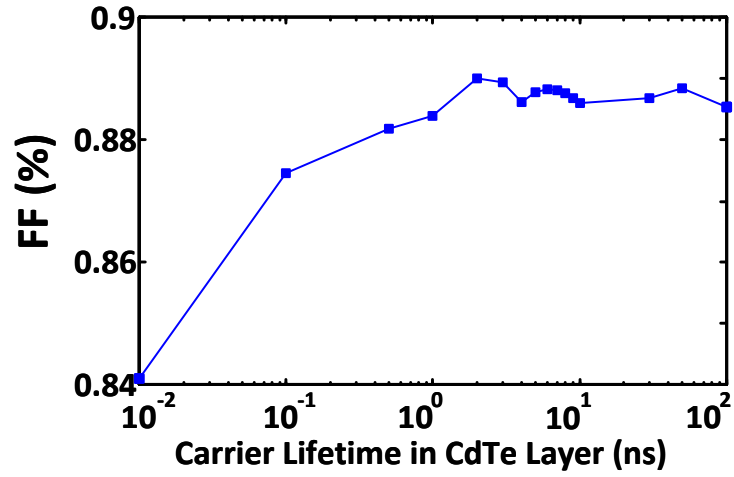

(b)

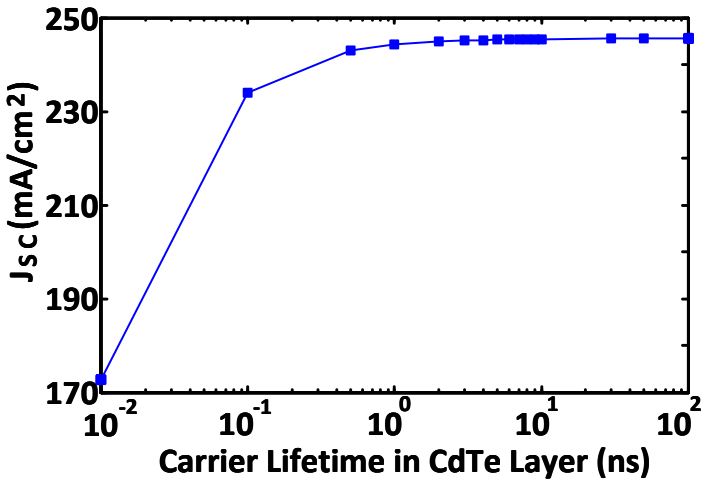

(d)

Figure 10: The variation of $\mathrm{J}_{\mathrm{sc}}, \mathrm{V}_{\mathrm{OC}}, \mathrm{FF}$ and Efficiency of the proposed cell as a function of the CdTe layer's carrier lifetime.

\section{REFERENCES}

Amin, N., Sopian, K., \& Konagai, M. (2007). Numerical modeling of CdS/CdTe and CdS/CdTe/ZnTe solar cells as a function of CdTe thickness. Solar Energy Materials and Solar Cells, 91, 1202-1208.

Aramoto, T., Ohyama, H., \& Kumazawa, S. (1997). 16.0\% Efficient thin film CdS-CdTe solar. Jpn. J. Appl. Phys., 36, 6304-6305.

Britt, J., \& Ferekides, C. (1993). Thin-film CdS/CdTe solar cell with $15.8 \%$ efficiency. Applied Physics Letters, 62, 2851-2852.

Colegrove, E., Banai, R., Blissett, C., Buurma, C., Ellsworth, J., Morley, M., \& Sivananthan, S. (2012). High-Efficiency Polycrystalline CdS/CdTe Solar Cells on Buffered Commercial TCOCoated Glass. Journal of Electronic Materials, 41, 2833-2837.

First Solar Inc., http://investor.firstsolar.com/releasedetail.cfm?, 2014 
Green, M. A., Emery, K., Hishikawa, Y., Warta, W., \& Dunlop, E. D. (2016). Solar cell efficiency tables (version 48). Progress in Photovoltaics: Research and Applications, 24, 905-913.

http://www.silvaco.com/products/device_simulation/atlas.html.

Jensen, S. A., Burst, J. M., Duenow, J. N., Guthrey, H. L., Moseley, J., Moutinho, H. R., \& Metzger, W. K. (2016). Long carrier lifetimes in large-grain polycrystalline $\mathrm{CdTe}$ without $\mathrm{CdCl} 2$. Applied Physics Letters, 108, 263903.

Khosroabadi, S., Keshmiri, S. H., \& Marjani, S. (2014). Design of a high efficiency CdS/CdTe solar cell with optimized step doping, film thickness, and carrier lifetime of the absorption layer. Journal of the European Optical Society: Rapid Publications, 9, 891-896.

Kosyachenko, L., Savchuk, A., \& Grushko, E. (2009). Dependence of efficiency of thin-film $\mathrm{CdS} / \mathrm{CdTe}$ solar cell on parameters of absorber layer and barrier structure. Thin Solid Films, 517, 2386-2391.

Krishnakumar, V., Han, J., Klein, A., \& Jaegermann, W. (2011). CdTe thin film solar cells with reduced CdS film thickness. Thin Solid Films, 519, 7138-7141.

Mahoodi, M., \& Marjani, S. (2017). Performance enhancement of polycrystalline CdS/CdTe solar cell by diffraction grating and engineering layers. The 8th National Conference on Physics, 223-227.

Mahoodi, M., \& Marjani, S. (2017). Enhanced photovoltaic performance of ultrathin polycrystalline $\mathrm{CdS} / \mathrm{CdTe}$ solar cell via indium antimonide absorber layer. The 2nd International Conference on Electrical Engineering (IC-EE)s, 1-4.

Mahoodi, M., \& Marjani, S. (2017). High-efficiency polycrystalline CdS/CdTe/InSb/CdTe solar cell with step doping grading of absorber and back surface field layers. The 4th National Conference on Information Technology, Computer and Telecommunication (ITCT), 1-7.

Mahoodi, M., Peiravi, A., \& Marjani, S. (2018). Time to failure analysis of polycrystalline $\mathrm{CdS} / \mathrm{CdTe} / \mathrm{InSb} / \mathrm{CdTe}$ solar cells. The 8th International Conference on Nanotechnology (ICN), 1-3.

Marjani, S., Khosroabadi, S., \& Sabaghi, M. (2016). A high efficiency ultrathin CdTe solar cell for nano-area applications. Optics and Photonics Journal, 6, 15-23.

Peña, J., Arés, O., Rejón, V., Rios-Flores, A., Camacho, J. M., Romeo, N., \& Bosio, A. (2011). A detailed study of the series resistance effect on $\mathrm{CdS} / \mathrm{CdTe}$ solar cells with $\mathrm{Cu} / \mathrm{Mo}$ back contact. Thin Solid Films, 520, 680-683.

Razykov, T., Ferekides, C., Morel, D., Stefanakos, E., Ullal, H., \& Upadhyaya, H. (2011). Solar photovoltaic electricity: Current status and future prospects. Solar Energy, 85, 1580-1608.

Rios-Flores, A., Arés, O., Camacho, J. M., Rejon, V., \& Peña, J. (2012). Procedure to obtain higher than $14 \%$ efficient thin film CdS/CdTe solar cells activated with HCF2Cl gas. Solar Energy, 86, 780-785.

Sabaghi, M., Majdabadi, A., Khosroabadi, S., \& Marjani, S. (2015). A novel ultrathin CdS/CdTe solar cell with conversion efficiency of $31.2 \%$ for nano-area application. The Progress in Electromagnetics Research Symposium (PIERS), 1152-1155.

Sabaghi, M., Majdabadi, A., Marjani, S., \& Khosroabadi, S. (2015). Optimization of high-efficiency $\mathrm{CdS} / \mathrm{CdTe}$ thin film solar cell using step doping grading and thickness of the absorption layer. Orient. J. Chem.,, 31, 891-896.

Wu, X., Keane, J.C., Dhere, R.G., Dehart, C., Albin, D. S., Duda, A., Gessert, T. A., Asher, S., Levi, D. H., \& Sheldon, P. (2001). 16.5\% Efficient CdS/CdTe polycrystalline thin film solar cell. 17th Conf. IEEE European Photovoltaic Solar Energy, 995-1000. 